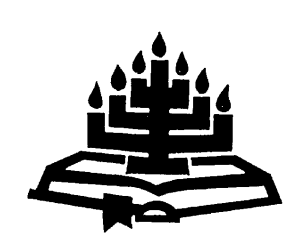

\title{
Op pad na 'n volwasse gemeente - 'n empiriese ondersoek met die oog op die ontwikkeling van 'n bedieningsmodel
}

\author{
G. Breed \& J. de Kock \\ Eenheid vir Reformatoriese Teologie \\ Potchefstroomkampus \\ Noordwes-Universiteit \\ POTCHEFSTROOM \\ E-pos: gert.breed@nwu.ac.za \\ janidk@gmail.com
}

\begin{abstract}
Towards a mature congregation - an empirical study of the development of a ministry model

This article describes an empirical study conducted in the Reformed Church Randburg during January 2009. The objective of the study was to gather information with the aim of improving or modifying the congregation's ministry model in terms of ministering within the congregation. The congregation's initiatives outside of the congregation were not addressed. The ultimate goal is a congregation of which the members serve each other, as God prescribes in his Word, and as such, mature to the glory of his Name. Firstly, the role that an empirical study should play within the development of a ministry model is discussed. Then, the historical run-up to the empirical study within the Reformed Church Randburg is described. This includes the ministry model followed up to the time of the study, as well as the degree to which it was successful. The research methodology and its results are then discussed. In conclusion, the guidelines deduced from the results of the research for the development of a ministry model are discussed.
\end{abstract}

\section{Opsomming}

Op pad na 'n volwasse gemeente - 'n empiriese ondersoek met die oog op die ontwikkeling van 'n bedieningsmodel

Hierdie artikel beskryf 'n empiriese studie wat gedoen is in die Gereformeerde Kerk Randburg tydens Januarie 2009. Die doel van hierdie studie was die insameling van inligting, met die oog 
op die verbetering of verandering van die gemeente se bedieningsmodel ten opsigte van die bediening binne die gemeente. Die bediening van die gemeente na buite is nie in die ondersoek hanteer nie. Die uiteindelike doel is 'n gemeente wat mekaar bedien soos God dit in sy Woord voorskryf, en wat groei tot volwassenheid ter ere van sy Naam. Eerstens word die plek wat ' $n$ empiriese ondersoek in die ontwikkeling van 'n bedieningsmodel van 'n gemeente behoort in te neem, bespreek. Daarna word die historiese aanloop tot die empiriese ondersoek binne die Gereformeerde Kerk Randburg beskryf. Dit sluit die bedieningsmodel in wat tot en met die ondersoek gevolg is, asook die mate van sukses wat daarmee behaal is. Hierna word die navorsingsmetodologie asook die resultate van die navorsing bespreek. Ten slotte word riglyne vir die ontwikkeling van 'n bedieningsmodel vanuit die resultate van die navorsing voorgehou.

\section{Inleiding}

Hierdie artikel beskryf 'n empiriese studie wat gedurende Januarie 2009 in die Gereformeerde Kerk Randburg gedoen is. Die doel van die studie was die insameling van inligting met die oog op die verbetering of verandering van die gemeente se bedieningsmodel ten opsigte van die bediening binne die gemeente. Die bediening van die gemeente na buite word nie in die ondersoek behandel nie. Die uiteindelike doel is 'n gemeente wat mekaar bedien soos God dit in sy Woord voorskryf en wat groei tot volwassenheid tot eer van sy Naam. In die eerste plek word die plek wat 'n empiriese ondersoek in die ontwikkeling van 'n bedieningsmodel van 'n gemeente behoort in te neem, bespreek. Daarna word die historiese aanloop tot die empiriese ondersoek binne die Gereformeerde Kerk Randburg beskryf. Dit sluit die bedieningsmodel in wat tot en met die ondersoek gevolg is, asook die mate van sukses wat daarmee behaal is. Hierna word die navorsingsmetodologie asook die resultate van die navorsing bespreek. Ten slotte word riglyne vir die ontwikkeling van 'n bedieningsmodel vanuit die resultate van die navorsing voorgehou.

\section{Die plek van 'n empiriese ondersoek}

Wanneer 'n gemeente 'n empiriese ondersoek doen, is dit belangrik om die plek wat daardie ondersoek en die resultate daarvan moet inneem, te bepaal.

Die vertrekpunt van enige bedieningsmodel in 'n gemeente moet die Woord van God wees. Uit die Woord moet die doelwit en die inhoud van die bediening bepaal word. Die Woord gee riglyne oor die ge- 
sindheid waarin die bediening moet plaasvind asook sekere riglyne oor die struktuur van die bediening. Hierdie riglyne wat uit die Skrif verkry is, moet na die praktiese situasie van die gemeente oorgedra en toegepas word sodat dit effektief dien tot opbou van die gemeente en die gemeentelede se groei na volwassenheid. Om die oorgang doeltreffend te kan doen, speel empiriese navorsing 'n baie belangrike rol (Heimbrock, 2005:275; Struwig, 2004:79).

Nel (2009:2) wys op die weerstand wat verandering in 'n gemeente kan wek. Hy bepleit die noodsaak van ontleding in 'n gemeente en dat besluite wat ten opsigte van gemeentebou geneem word, gegrond sal wees op data wat ingesamel is. Hiersonder kan besluite in die gemeente moontlik op voorgevoelens, vrese of tradisies gegrond word. Hy (Nel, 2009:6) haal Callahan aan wat sê dat 'n gemeente sy sterk punte moet sien as gawes van God, en dat hy hierdie gawes moet omarm as 'n krag van God binne die gemeente. Die gemeente moet vra hoe die sterk punte uitgebou kan word om God se opdrag doeltreffender uit te voer.

Schwarz (1996:13-14) sluit hierby aan deur klem te lê op die ontsluiting van die groeipotensiaal wat God in 'n gemeente inbou. Groeiprogramme moenie aan 'n gemeente opgedwing word nie, maar die natuurlike potensiaal moet benut word. Hierdie benadering het nie in die eerste plek getallegroei ten doel nie, maar beskou die gehalte van die gemeentelewe as die sleutel tot groei. 'n Bloot pragmatiese benadering word dus verwerp en bybelse beginsels word eerder as vertrekpunt geneem.

Woolever en Bruce (2004:3) wys op die uniekheid van elke gemeente met sy eie verhaal en sy eie blik op die werklikheid (vgl. ook Van der Ven, 2002:7). Deur 'n empiriese ondersoek kan die unieke eienskappe van 'n gemeente beter verstaan word: wat die besondere gawes is en waarvoor gemeentelede in hulle gemoed gereed is (vgl. Van der Ven, 2002:10).

\section{Die aanloop tot die empiriese ondersoek}

\subsection{Bedieningsmodel}

Die Gereformeerde Kerk Randburg is 'n stadsgemeente wat ten tye van die ondersoek uit sowat 1071 belydende lidmate bestaan het. Die meeste lidmate wat aan die ondersoek deelgeneem het, het universiteitsopleiding en het óf hulle eie ondernemings, óf werk in 'n professionele kapasiteit. Sowat die helfte van die gemeente is tus- 
sen 18 en 40 jaar oud. 'n Verdere $30 \%$ van die gemeente is tussen 40 en 60 jaar oud.

Voordat die empiriese ondersoek gedoen is, het die gemeente reeds vir ongeveer drie jaar 'n bepaalde bedieningsmodel gevolg, wat daarop gemik was om die gemeente toe te rus vir sy dienswerk om onderlinge liefde in die gemeente te bevorder en uit te reik na buite. Die bedieningsmodel het in die gemeente as "mekaar-bediening" of "lidmate-kerk" bekend gestaan. Die model is gegrond op Efesiërs 4 asook die verskillende tekste in die Bybel waar die gelowiges aangespoor word om "mekaar te bedien" (vgl. Versteeg,1980). Die empiriese ondersoek het ten doel gehad om hierdie model te verfyn of te verander, in die lig van die inligting wat uit die ondersoek verkry sou word.

Kruger (2005:534-545) se verklaring van Efesiërs 4 met betrekking tot die funksionering van 'n gemeente kan soos volg voorgestel word:

\section{Tabel 1: Die funksionering van die gemeente na aanleiding} van Efesiërs 4

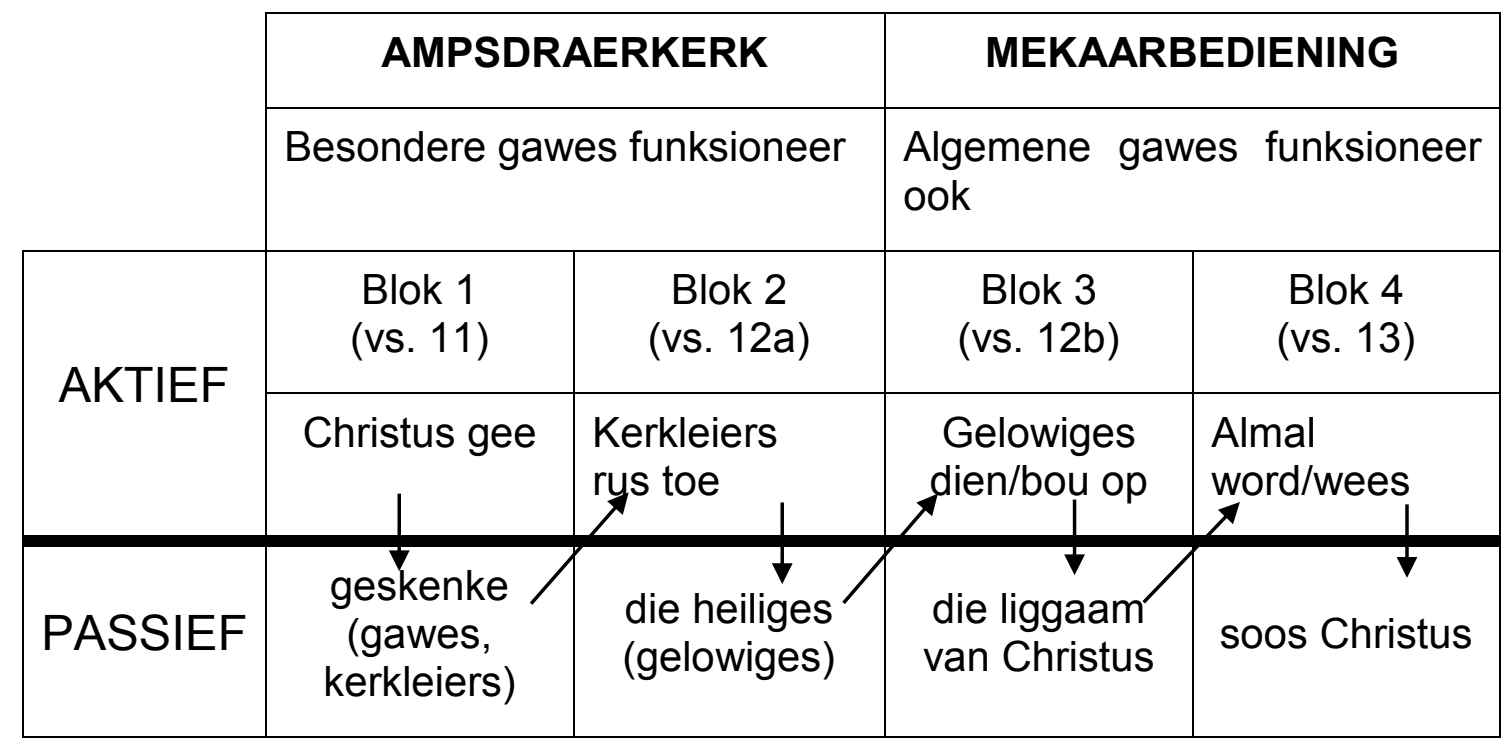

Vanuit Efesiërs 4 beklemtoon die voorstelling Christus as die gewer van alle gawes (blok 1), en dat Hy die eindpunt van die groei van die gemeente is (blok 4). Hy gee dus gawes aan die gemeente sodat die lede deur die benutting daarvan kan groei om meer en meer soos $\mathrm{Hy}$ te word. Om hierdie groei te laat plaasvind, is dit egter belangrik om die gawes wat Hy gee, aan te wend vir die spesifieke doel waarvoor Hy dit gee. In blok 1 (Ef. 4:11) is die kerkleiers die ontvangers van die gawes en daardeur word hulle self gawes aan 
die gemeente. In blok 2 (Ef. 4:12a) word beskryf waarvoor die kerkleiers hulle gawes moet gebruik, naamlik om gelowiges toe te rus vir hulle dienswerk. Die gelowiges is in hierdie blok die ontvangers van die toerusting. In blok 3 (Ef. 4:12b) word beskryf waarvoor die toerusting aangewend moet word, naamlik dienswerk binne die gemeente. Hier is die gemeente die ontvanger van mekaar se dienswerk. In blok 4 word die resultaat beskryf van dit wat in blok 1 tot 3 plaasvind, naamlik dat daar groei in die gemeente sal wees en die eindresultaat is dat Christus in die gemeente gestalte kry.

Indien die prosesse in blok 2 stagneer (vgl. die vertikale lyn), word die gemeentelede passiewe ontvangers van die bediening, en gaan hulle nie daartoe oor om mekaar te bedien nie. Die werk wat volgens blok 3 gedoen moet word, bly dan ongedaan óf die kerkleiers begin ook daarvoor instaan. Dit het tot gevolg dat hulle die toerusting van lidmate nog meer afskeep (blok 2), en ook nie die bediening (blok 3) kan doen soos wat Christus dit bedoel het nie (vgl. Hand. 2; Breed \& Breed, 2010:627-653). Die gevolg hiervan is dat die groei wat in blok 4 moet plaasvind, gebrekkig is (vgl. ook Kruger, 2005:539-540).

Op grond van Efesiërs 4 is in die bedieningstrategie van die gemeente sterk klem gelê op toerusting, gemeenskap, uitreik en beplanning.

\section{- Toerusting}

- Kerkleiers en kategete is toegerus om te begryp wat hulle roeping is.

- Ouderlinge is toegerus vóór hulle huisbesoek gaan doen het, sodat hulle weer die gemeente kon toerus.

- Daar is voortdurend toerustingskursusse in die gemeente aangebied, gemik op die praktiese uitleef van die geloof sodat die gemeente tot volwassenheid in Christus kan groei en die lede standvastig in hulle geloof kan wees (Ef. 4:13-14).

- 'n Bybelskool is begin waar lidmate toegerus kon word in kennis van die hele Bybel.

- Sterk klem is gelê op die gehalte van die onderrig in sowel die kategese as die prediking. 


\section{- Gemeenskap}

- Baie moeite is gedoen om die erediens werklik 'n onmoeting met die drie-enige God te maak.

- Bybelstudiegroep- en kleingroepbediening is doelbewus bevorder en uitgebou.

- Die diakens se werk is nader gedefinieer as "omgeebediening". Dit het behels dat die diaken in sy wyk die mense wat meelewend, beskikbaar en bereid is, moet identifiseer. Die diaken moet hierdie gelowiges se gawes benut om mense in sy wyk wat om die een of ander rede nie voluit deel van die gemeente is nie, te probeer intrek en met die liefde van Christus te bedien.

\section{- Uitreik}

- Die gemeente het 'n predikant beroep en na Londen gestuur om daar 'n gemeente te stig met die oog op die bediening van SuidAfrikaners, maar uiteindelik ook om die evangelie in Londen uit te dra.

- Die gemeente het gelowiges in die Diepsloot-plakkerskamp bedien en hulle as 'n wyk van die gemeente verwelkom, en uiteindelik ook 'n predikant beroep wat hulle in hulle eie taal (Sotho en Zoeloe) kan bedien.

- In die prediking en in die Bybelstudiegroepe is mense toegerus om die evangelie in die gang van hulle lewens aan ander oor te dra.

- 'n Engelse bediening is begin deur 'n Bybelstudiegroep te stig en 'n vertaaldiens in die erediens in te stel.

\section{- Beplanning}

- Voortdurende beplanning het deel geword van die gemeentestrategie. ' $n$ Diensgroep is gestig wat voortdurend evaluering en beplanning moet doen. Elke jaar is 'n groot beplanningsberaad gehou waar evaluering gedoen is van die vordering en nuwe planne op die tafel gesit is.

\subsection{Sukses}

Al hierdie dinge is met ' $n$ mindere of meerdere mate van sukses beloon. Die een groot tekortkoming wat telkens uitgewys is, is dat die mense wat reeds in die gemeente betrokke was, meer betrokke geraak het, maar dat min wat onbetrokke was, betrokke geraak het. 
Die omgeebediening deur die diakens het gesukkel om van die grond af te kom en daar is slegs enkele lidmate wat bereid was om ander te besoek. Diakens was nie werklik gemotiveerd of het nie toegerus gevoel om omgeebediening in hulle wyke te begin nie. Dit was duidelik dat die bediening grootliks vashaak in blok 2 van die Efesiërs 4-bedieningsmodel. Die vraag het ontstaan hoe ver die gemeente ingekoop het in die bedieningsmodel en hoe hulle hulle deelwees van die gemeente ervaar. Is daar gawes wat die Here aan hierdie gemeente gegee het wat onder- of glad nie benut word nie? Daarom is besluit om ' $n$ empiriese ondersoek in die gemeente te doen en die data dan te gebruik om die bedieningsplan te verfyn of ingrypend te verander indien nodig. Die beginsels uit die Skrif was nie onderhandelbaar nie, maar die oortuiging was dat duidelikheid uit die data verkry kan word oor die wyse waarop hierdie beginsels in die praktyk toegepas kan word.

\section{Die metodologie van die empiriese ondersoek}

\subsection{Die navorsingsprobleem}

Soos reeds uiteengesit, is 'n struikelblok tussen blok 2 en 3 in die Efesiërs 4-bedieningsmodel geïdentifiseer. Dit wou lyk asof die bediening primêr deur die kerkraad aan die gemeente geskied - wat lynreg in teenstelling met 'n mekaarbediening staan. In 'n mekaarbediening is gemeentelede aktief betrokke op verskeie vlakke van bediening. Die navorsingsprobleem was daarom om te verstaan hoe die gemeente verby hierdie struikelblok kon beweeg na 'n werklike mekaarbediening. Die eerste twee hipoteses $(\mathrm{H} 1$ en $\mathrm{H} 2)$ is daarom as volg met die aanvang van die navorsing geformuleer:

H1: 'n Struikelblok bestaan tussen blok 2 en 3 van die Efesiërs 4-bedieningsmodel in die gemeente, deurdat bediening primêr van kerkraadslede na gemeentelede vloei.

H2: Dit is moontlik om die bedieningskultuur van die gemeente so te verander dat gemeentelede aktief betrokke raak by 'n mekaarbediening.

\subsection{Navorsingsmetodologie}

Die navorsingsontwerp het bestaan uit 'n gekombineerde kwalitatiewe en kwantitatiewe metodologie. Kwantitatiewe en kwalitatiewe navorsing word gereeld gekombineer wanneer onafhanklike veranderlikes (of die faktore wat ' $n$ impak op die onafhanklike veranderlike het - in hierdie geval betrokkenheid by die kerk), nie bekend is nie (Mariampolski, 2001:22; vgl. Van der Ven, 2002:8). Voor 'n kwan- 
titatiewe meetinstrument ontwikkel kon word, was dit nodig om die moontlike faktore wat 'n impak op kerkbetrokkenheid kon hê, te identifiseer. Tabel 2 is 'n opsomming van die metodologie wat in die empiriese ondersoek gevolg is:

\section{Tabel 2: Die fases van die empiriese ondersoek}

\begin{tabular}{|l|l|l|l|}
\hline & Navorsingsfase & Doel & Beskrywing \\
\hline 1 & $\begin{array}{l}\text { Kwalitatiewe } \\
\text { ondersoek }\end{array}$ & $\begin{array}{l}\text { Identifiseer faktore wat ge- } \\
\text { meente se belewing beïn- } \\
\text { vloed, met die doel om 'n } \\
\text { kwantitatiewe vraelys op te } \\
\text { stel. }\end{array}$ & \\
\hline 2 & $\begin{array}{l}\text { Formulering van } \\
\text { hipoteses }\end{array}$ & $\begin{array}{l}\text { Voer kwantitatiewe fase uit, } \\
\text { gefokus op die oplossing } \\
\text { van die navorsingspro- } \\
\text { bleem. }\end{array}$ & $\begin{array}{l}\text { Herformuleer kernbe- } \\
\text { vindings uit kwalitatie- } \\
\text { we navorsing as hipote- } \\
\text { ses }\end{array}$ \\
\hline 3 & $\begin{array}{l}\text { Kwantitatiewe } \\
\text { ondersoek }\end{array}$ & $\begin{array}{l}\text { Verkry begrip vanuit 'n sta- } \\
\text { tistiesverteenwoordigende } \\
\text { steekproef. }\end{array}$ & 371 self-invulvraelyste. \\
\hline
\end{tabular}

\subsection{Metode en steekproef vir Fase 1: kwalitatiewe navorsing}

Die kwalitatiewe navorsingsfase het bestaan uit fokusgroepe wat met gemeentelede gehou is. Altesame tien fokusgroepe met gemeentelede in verskillende lewensfases is gehou. Tabel 3 is ' $n$ opsomming van die steekproef van die kwalitatiewe fase.

\section{Tabel 3: Kwalitatiewe steekproef}

\begin{tabular}{|l|l|l|l|}
\hline Groep & $\begin{array}{l}\text { Wyks- } \\
\text { indeling }\end{array}$ & Beskrywing & $\begin{array}{l}\text { Deelname in aktiwiteite } \\
\text { by die kerk }\end{array}$ \\
\hline 1 & A & Pensioentrekkers & $\begin{array}{l}\text { Gemeng - aktief en nie } \\
\text { aktief betrokke by kerkak- } \\
\text { tiwiteite }\end{array}$ \\
\hline 2 & B & $\begin{array}{l}\text { Getroude paartjies wie se se } \\
\text { kinders reeds uit die skool is }\end{array}$ & $\begin{array}{l}\text { Gemeng - aktief en nie } \\
\text { aktief betrokke by kerk- } \\
\text { aktiwiteite }\end{array}$ \\
\hline 3 & C & $\begin{array}{l}\text { Getroude paartjies met kin- } \\
\text { ders op skool }\end{array}$ & $\begin{array}{l}\text { Aktief betrokke by kerk- } \\
\text { aktiwiteite }\end{array}$ \\
\hline 4 & C & $\begin{array}{l}\text { Getroude paartjies met kin- } \\
\text { ders op skool }\end{array}$ & $\begin{array}{l}\text { Nie aktief betrokke by } \\
\text { kerkaktiwiteite }\end{array}$ \\
\hline
\end{tabular}




\begin{tabular}{|l|l|l|l|}
\hline Groep & $\begin{array}{l}\text { Wyks- } \\
\text { indeling }\end{array}$ & Beskrywing & $\begin{array}{l}\text { Deelname in aktiwiteite } \\
\text { by die kerk }\end{array}$ \\
\hline 5 & D & $\begin{array}{l}\text { Jonggetroude paartjies son- } \\
\text { der kinders }\end{array}$ & $\begin{array}{l}\text { Aktief betrokke by kerk- } \\
\text { aktiwiteite }\end{array}$ \\
\hline 6 & E & Ongetroude jongmense & $\begin{array}{l}\text { Aktief betrokke by kerk- } \\
\text { aktiwiteite }\end{array}$ \\
\hline 7 & D/E & $\begin{array}{l}\text { Jonggetroude paartjies son- } \\
\text { der kinders en ongetroude } \\
\text { jongmense }\end{array}$ & $\begin{array}{l}\text { Nie aktief betrokke by } \\
\text { kerkaktiwiteite }\end{array}$ \\
\hline 8 & - & $\begin{array}{l}\text { Diakens } \\
\text { Oktief betrokke by kerk- } \\
\text { aktiwiteite }\end{array}$ \\
\hline 10 & - & Ouderlinge & $\begin{array}{l}\text { Aktief betrokke by kerk- } \\
\text { aktiwiteite }\end{array}$ \\
\hline
\end{tabular}

Die samestelling van elke groep is so homogeen as moontlik gehou om te verseker dat bevindings so spesifiek moontlik sou wees tot gemeentlede in verskillende lewensfases. 'n Poging is ook aangewend om gemeentelede wat by aktiwiteite in die kerk betrokke was, sowel as gemeentelede wat nie by aktiwiteite in die kerk betrokke was nie by die steekproef in te sluit. Alle groepe het manlike en vroulike gemeentelede ingesluit.

Fokusgroepe is deur 'n marknavorser gefasiliteer wat onafhanklik van die gemeente se leierskap was. Elke fokusgroep het tussen ses en agt deelnemers gehad. Waar moontlik is die groepsbyeenkomste gehou op 'n perseel weg van die kerkgebou, en die groepe is nie deur enige verteenwoordigers van die kerkleierskap bygewoon nie, ten einde 'n oop bespreking te bevorder.

\subsection{Metode en steekproef vir kwantitatiewe navorsing}

Faktore wat moontlik betrokkenheid by kerkaktiwiteite beïnvloed, is tydens die kwalitatiewe fase geïndentifiseer. Hierdie faktore is in die kwantitatiewe fase geverifieer. 'n Self-invulvraelys is opgestel en op 'n Sondag gedurende die oggend- en aanderedienste uitgedeel. Om respondentuitputting te verminder, is die vraelys vóór die aanvang van elke erediens uitgedeel. Dit is ook die daaropvolgende Maandag elektronies na die gemeente uitgestuur. Die elektroniese verspreiding van die vraelys het nie 'n groot uitkoms gelewer nie en toekomstige studies behoort nie slegs van hierdie data-insamelingsmetode gebruik te maak nie. Gemeentelede is gevra om slegs eenmalig die vraelys in te vul. (Indien 'n gemeentelid dus albei die Son- 
dageredienste bywoon en die vraelys elektronies ontvang, moes hy/sy slegs een keer die vraelys voltooi). Die totale kwantitatiewe steekproef was 371 . Die foutspeling was slegs 4,1 (bereken vir die $95 \%$-sekerheidsinterval vir 'n totale populasie van 1074 belydende lidmate). Tabel 4 is 'n opsomming van die samestelling van die kwantitatiewe steekproef.

Die vraelys maak meestal gebruik van tienpuntvrae waar die respondent gevra word tot welke mate hy/sy saamstem met 'n stelling wat gemaak word. 'n Tienpuntskaal is gebruik omdat dit meer variansie in die data verseker en omdat daar dan nie 'n maklike middelwaarde-uitweg is nie. Waar relevant, is die data volgens demografiese eienskappe ontleed (soos uiteengesit in Tabel 4) en ook volgens betrokkenheid. Sommige aspekte van die empiriese ondersoek kon nie in 'n skaalvraag geformuleer word nie. Hierdie data is as persentasies weergegee. Dit word aangedui by die bespreking van die betrokke faktore in punt 5.2.

Respondente het aangedui by watter diensgroepe of aktiwiteite hulle by die kerk betrokke is. Op grond van hierdie vraag is ' $n$ indeks saamgestel wat die steekproef in drie segmente van betrokkenheid verdeel. Elke aktiwiteit is subjektief as 'n "gee"- of "ontvang"- aktiwiteit geklassifiseer. So is "feesaande deelneem" geklassifiseer as 'n "ontvang-aktiwiteit", en "feesaande reël" as 'n "gee-aktiwiteit". Aktiwiteite wat 'n aktiewe bydrae van betrokkenes verg ("gee-aktiwiteite") het 'n hoër waarde ontvang as aktiwiteite waar lidmate meer ontvang as gee ("ontvang-aktiwiteite"). 
Tabel 4: Kwantitatiewe steekproef

\begin{tabular}{|l|l|}
\hline Geslag & \\
\hline Manlik & $46 \%$ \\
\hline Vroulik & $49 \%$ \\
\hline $\begin{array}{l}\text { Geen } \\
\text { waarde }\end{array}$ & $5 \%$ \\
\hline
\end{tabular}

\begin{tabular}{|l|c|}
\hline $\begin{array}{l}\text { Tyd in die } \\
\text { gemeente* }\end{array}$ & \\
\hline $\begin{array}{l}\text { Minder as } \\
\text { maande }\end{array}$ & $7 \%$ \\
\hline $6-12$ maande & $6 \%$ \\
\hline $1-3$ jaar & $18 \%$ \\
\hline $4-6$ jaar & $19 \%$ \\
\hline $7-10$ jaar & $9 \%$ \\
\hline $11-15$ jaar & $7 \%$ \\
\hline $16-20$ jaar & $6 \%$ \\
\hline $20+$ jaar & $21 \%$ \\
\hline Geen waarde & $7 \%$ \\
\hline
\end{tabular}

\begin{tabular}{|l|l|}
\hline Lewensfase & \\
\hline Pensioentrekkers & $13 \%$ \\
\hline $\begin{array}{l}\text { Paartjies sonder } \\
\text { kinders op skool }\end{array}$ & $19 \%$ \\
\hline $\begin{array}{l}\text { Gesinne-paartjies } \\
\text { met kinders op } \\
\text { skool (en kinders) }\end{array}$ & $27 \%$ \\
\hline $\begin{array}{l}\text { Jonggetroude sonder } \\
\text { paartjies } \\
\text { kinders }\end{array}$ & $14 \%$ \\
\hline $\begin{array}{l}\text { Ongetroude jong } \\
\text { volwassenes }\end{array}$ & $19 \%$ \\
\hline Geen waarde & $6 \%$ \\
\hline
\end{tabular}

\begin{tabular}{|l|l|}
\hline Ouderdom & \\
\hline Hoërskool & $2 \%$ \\
\hline $19-24$ & $8 \%$ \\
\hline $25-29$ & $18 \%$ \\
\hline $30-39$ & $18 \%$ \\
\hline $40-49$ & $14 \%$ \\
\hline $50-59$ & $12 \%$ \\
\hline $60-69$ & $14 \%$ \\
\hline $70-79$ & $7 \%$ \\
\hline $80+$ & $1 \%$ \\
\hline $\begin{array}{l}\text { Geen } \\
\text { waarde }\end{array}$ & $6 \%$ \\
\hline
\end{tabular}

\begin{tabular}{|l|l|}
\hline $\begin{array}{l}\text { Rol in die ge- } \\
\text { meente }\end{array}$ & \\
\hline Ouderlinge & $12 \%$ \\
\hline Diakens & $8 \%$ \\
\hline Gemeentelede & $80 \%$ \\
\hline
\end{tabular}

\begin{tabular}{|l|l|}
\hline $\begin{array}{l}\text { Besoekers (nie } \\
\text { gemeentelede) }\end{array}$ & $2 \%$ \\
\hline
\end{tabular}

\begin{tabular}{|l|l|}
\hline Betrokkenheid & \\
\hline Baie betrokke & $10 \%$ \\
\hline Matig betrokke & $38 \%$ \\
\hline Onbetrokke & $52 \%$ \\
\hline
\end{tabular}

Die segmente is soos volg gedefinieer:

- Baie betrokke: drie of meer "gee-aktiwiteite"

- Matig betrokke: een tot twee "gee-aktiwiteite", of minstens twee "ontvang-aktiwiteite" 
- Onbetrokke: geen of slegs een “ontvang”-aktiwiteit

\section{Kwalitatiewe navorsingsbevindings}

Die data is gedurende die kwalitatiewe fase deur middel van fokusgroepe versamel. Die ongestruktureerde gesprek gedurende die fokusgroepe het die volgende breë temas ingesluit: Die gesprek is eerstens ingelei met 'n bespreking van die lidmate se lewenstyl en persoonlike geloofskonteks. Dit het 'n bespreking van hulle waardes, vryetydsbesteding en mediagebruik ingesluit. Daarna is 'n bespreking gevoer van die Randburg-gemeente se belewing met betrekking tot die gemeente se unieke eienskappe en lidmate se ervaring van hulle rol binne hierdie konteks. Die mekaarbediening het daarna regstreeks aandag gekry ten einde te ondersoek tot watter mate lidmate bewus was van die bedieningsmodel en of die bedieningsmodel werklik begryp word. Die groepe het afgesluit met die identifisering van faktore wat hulle betrokkenheid by die bediening verhinder en moontlik kon bevorder.

Die data is deur 'n gestruktureerde proses van drie stappe ontleed (Ryan \& Bernard, 2003:85; Ratner, 2001:1-4). Eerstens is temas en subtemas geïdentifiseer wat die inherente betekenis van die belangrikste grepe uit die bespreking opgesom het. Tweedens is hierdie temas in verbandhoudende groepe gerangskik. Laastens is die temas geprioritiseer om 'n hiërargie van temas daar te stel wat die kern van die bevindings proporsioneel kon voorstel. Hierdie hiërargie is in hipoteses omskryf wat in die kwantitatiewe fase bevestig kon word.

\subsection{Kwalitatiewe bevindings as hipoteses}

Die volgende kwalitatiewe bevindings is in die kwantitatiewe fase as hipoteses $(\mathrm{H} 3-\mathrm{H} 10)$ getoets:

H3: Individuele betrokkenheid word verhinder deur 'n persoonlike gevoel van onbekwaamheid en 'n gebrek aan kennis.

H4: Betrokkenheid word verhinder deur 'n gebrek aan persoonlike verantwoordelikheidsbesef.

H5: Betrokkenheid word benadeel deur 'n algemene tekort aan vrye tyd in gemeentelede se persoonlike skedules.

H6: Die verskille in die lewensomstandighede, prioriteite en behoeftes van gemeentelede in verskillende lewensfases, het 'n beduidende invloed op hulle betrokkenheid in die gemeente. 
H7: Gemeentelede is oorafhanklik van die kerkleiers (ampte).

H8: Betrokkenheid sal bevorder word deur toerusting en take so spesifiek moontlik vir die individu te maak.

H9: Betrokkenheid sal bevorder word deur 'n gesindheidsverandering by gemeentelede oor die mekaarbediening.

H10: Gemeentelede is nie sosiaal met mekaar bekend nie en betrokkenheid sal bevorder word indien gemeentelede mekaar leer ken.

\subsection{Om gemeentelede in verskillende lewensfases te verstaan}

Hipotese 5 verwys na die invloed wat die beskikbaarheid van vrye tyd op betrokkenheid in die gemeente kan hê. Die Gereformeerde Kerk Randburg se wyke, asook die kwalitatiewe steekproef, is volgens lewensfase ingedeel. Soos genoem, het die kwalitatiewe fase 'n dieptestudie na lidmate se lewensomstandighede ingesluit. Die verskille en ooreenkomste in die vrye tyd en prioriteite van gemeentelede in verskillende lewensfases regverdig daarom bespreking.

Vrye tyd is vir die doel van die gesprek gedefinieer as enige tyd wat buite werk- of skoolverpligtings oorbly en sal tipies weeksaande, naweke en vakansies insluit (binne hierdie definisie is al die pensioentrekkers se tyd as "vrye tyd" geklassifiseer). Gemeentelede is ook gevra om die kerk as 'n denkbeeldige persoon voor te stel. Hierdie vraag is geformuleer in 'n poging om te verstaan in watter verhouding elke segment met die kerk staan. Laastens is gemeentelede gevra om te verduidelik hoe hulle betrokkenheid by kerkaktiwiteite binne hierdie breë lewensraamwerk inpas. Verskille is geïdentifiseer in die lewensomstandighede, prioriteite en behoeftes van die verskillende segmente. Tabel 5 lig die belangrikste verskille tussen die segmente uit. 
Tabel 5: Die verskille tussen gemeentelede in verskillende lewensfases

\begin{tabular}{|c|c|c|c|}
\hline & $\begin{array}{l}\text { Pensioentrek- } \\
\text { kers }\end{array}$ & $\begin{array}{l}\text { Gesinne met } \\
\text { volwasse kin- } \\
\text { ders (huisverla- } \\
\text { ters) }\end{array}$ & $\begin{array}{l}\text { Gesinne met kin- } \\
\text { ders in die huis }\end{array}$ \\
\hline Prioriteite & $\begin{array}{l}\text { Eggenootversor- } \\
\text { ging } \\
\text { Kinders } \\
\text { Eie belangstel- } \\
\text { lings }\end{array}$ & $\begin{array}{l}\text { Werk } \\
\text { Verhoudings } \\
\text { Breër familie } \\
\text { Kinders en klein- } \\
\text { kinders }\end{array}$ & $\begin{array}{l}\text { Gesin en veral kin- } \\
\text { ders } \\
\text { Finansiële druk } \\
\text { Voel impak van SEB }\end{array}$ \\
\hline $\begin{array}{l}\text { Die kerk as } \\
\text { denkbeeldige } \\
\text { persoon }\end{array}$ & $\begin{array}{l}\text { Goeie vriend/- } \\
\text { vriendin } \\
\text { Middeljarig met } \\
\text { genoeg ervaring, } \\
\text { maar nie te oud } \\
\text { om self versorging } \\
\text { nodig te hê nie }\end{array}$ & $\begin{array}{l}\text { Manlik } \\
\text { Ouer } \\
\text { Modern, maar } \\
\text { nie volksvreemd } \\
\text { nie }\end{array}$ & $\begin{array}{l}\text { Goeie vriend } \\
\text { Ondersteuningspilaar } \\
\text { By 'n kruispad - baie } \\
\text { om voor verskoning } \\
\text { te vra oor die ver- } \\
\text { lede, maar probeer } \\
\text { hard }\end{array}$ \\
\hline Vrye tyd & $\begin{array}{l}\text { Heelwat vrye tyd, } \\
\text { maar is baie se- } \\
\text { lektief in die keuse } \\
\text { van aktiwiteite } \\
\text { waaraan hulle } \\
\text { deelneem }\end{array}$ & $\begin{array}{l}\text { Vrye tyd bestee } \\
\text { aan: } \\
\text { Werk by die huis } \\
\text { verder } \\
\text { Direksies } \\
\text { Skryf, lees } \\
\text { Kleinkinders se } \\
\text { naskoolse } \\
\text { aktiwiteite }\end{array}$ & $\begin{array}{l}\text { Baie min werklike } \\
\text { vrye tyd wat nie deur } \\
\text { skoolaktiwiteite } \\
\text { opgeneem word nie } \\
\text { Gesin soms eers om } \\
\text { 19:00 almal tuis }\end{array}$ \\
\hline $\begin{array}{l}\text { Betrokkenheid } \\
\text { by kerk }\end{array}$ & $\begin{array}{l}\text { Weeksdae } \\
\text { Glad nie in die } \\
\text { aand } \\
\text { Nie oor naweke }\end{array}$ & $\begin{array}{l}\text { Geniet betrok- } \\
\text { kenheid by kerk- } \\
\text { aktiwiteite as ge- } \\
\text { leentheid om } \\
\text { goeie vriende te } \\
\text { sien }\end{array}$ & $\begin{array}{l}\text { Vind dit moeilik om } \\
\text { by kerkaktiwiteite be- } \\
\text { trokke te wees as } \\
\text { daar nie voorsiening } \\
\text { gemaak word vir kin- } \\
\text { ders nie }\end{array}$ \\
\hline
\end{tabular}


G. Breed \& J. de Kock

\begin{tabular}{|c|c|c|c|}
\hline & $\begin{array}{l}\text { Jonggetroudes } \\
\text { sonder kinders }\end{array}$ & Enkellopendes & Hoërskoolkinders \\
\hline Prioriteite & $\begin{array}{l}\text { Loopbaan- en fi- } \\
\text { nansiële vryheid } \\
\text { Jong huwelik } \\
\text { (“My man" of "My } \\
\text { vrou”) }\end{array}$ & $\begin{array}{l}\text { Finansiële } \\
\text { onafhanklikheid } \\
\text { Vestig loopbaan } \\
\text { Vestig verhou- } \\
\text { dings }\end{array}$ & $\begin{array}{l}\text { Akademie } \\
\text { Beroepskeuses }\end{array}$ \\
\hline $\begin{array}{l}\text { Die kerk as } \\
\text { denkbeeldige } \\
\text { persoon }\end{array}$ & $\begin{array}{l}\text { lemand vir wie ek } \\
\text { respek het } \\
\text { lemand by wie ek } \\
\text { veilig voel } \\
\text { lemand wat ek } \\
\text { trots is om te ken }\end{array}$ & $\begin{array}{l}\text { Ouer } \\
\text { Manlik } \\
\text { Respekteer hom } \\
\text { "Soos die MD } \\
\text { van 'n maat- } \\
\text { skappy" }\end{array}$ & $\begin{array}{l}\text { Vaderlike figuur } \\
\text { lemand wat jy kan } \\
\text { vertrou met jou pro- } \\
\text { bleme }\end{array}$ \\
\hline Vrye tyd & $\begin{array}{l}\text { Min vrye tyd } \\
\text { Werk laat en } \\
\text { stadsverkeer } \\
\text { Vrye tyd aan } \\
\text { vriende en fami- } \\
\text { lie; werk by die } \\
\text { huis; "nesskrop" }\end{array}$ & $\begin{array}{l}\text { Addisionele stu- } \\
\text { dies } \\
\text { Nesskrop } \\
\text { Baie sosiaal in } \\
\text { groter vriende- } \\
\text { kringe }\end{array}$ & $\begin{array}{l}\text { Baie besig met sport, } \\
\text { huiswerk, kultuurak- } \\
\text { sies } \\
\text { Kom gereeld eers } \\
\text { saans tuis }\end{array}$ \\
\hline $\begin{array}{l}\text { Betrokkenheid } \\
\text { by kerk }\end{array}$ & $\begin{array}{l}\text { Sosialiseer graag } \\
\text { by kerk. Voel vry- } \\
\text { moedig om ander } \\
\text { vriende (buite } \\
\text { kerk) saam te } \\
\text { bring. Verkies om } \\
\text { saam met le- } \\
\text { wensmaat betrok- } \\
\text { ke te wees }\end{array}$ & $\begin{array}{l}\text { Betrokkenheid } \\
\text { word bevorder } \\
\text { deur die moont- } \\
\text { likheid om te so- } \\
\text { sialiseer met an- } \\
\text { der enkellopen- } \\
\text { des/jong mense }\end{array}$ & $\begin{array}{l}\text { Kerkbetrokkenheid } \\
\text { ding mee met uiters } \\
\text { vol skoolkalender }\end{array}$ \\
\hline
\end{tabular}

\section{- Kwantitatiewe bevindings}

In die kwalitatiewe fase is verskeie struikelblokke en moontlike sleutels tot sukses geïdentifiseer. Hier word die relevansie van elk van hierdie aanvanklike hipoteses in die lig van die kwantitatiewe data 
bespreek en riglyne word getrek vir die beoordeling en ontwikkeling van die praktyk van die Efesiërs 4-bedieningsmodel.

\section{- Mekaarbedieningsgesindheid}

H1: 'n Struikelblok bestaan tussen blok 2 en 3 op die Efesiers 4bedieningsmodel in die gemeente deurdat bediening primêr van kerkraadslede na gemeentelede vloei. Dit is bevestig.

Die kerkleiers se aanvanklike hipotese dat daar 'n struikelblok tussen blok 2 en 3 in die model is, is in die studie bevestig. Tabel 6 kontrasteer lidmate se gesindheid teenoor die mekaarbediening met die werklikheid van aktiewe betrokkenheid by die bediening. Die waardes verteenwoordig die gemiddeld op 'n 10-punt-skaal, waar 10 gelyk is aan "Ek stem volkome saam" en 1 gelyk is aan "Ek stem glad nie saam nie".

\section{Tabel 6: Mekaarbedieningsgesindheid}

\begin{tabular}{|l|c|l|l|l|}
\hline \multirow{2}{*}{$\begin{array}{l}\text { Gemiddeld op } \\
\text { 'n 10- punt- } \\
\text { skaal }\end{array}$} & \multicolumn{2}{|l|}{ Glo in mekaarbediening } & \multicolumn{2}{l}{$\begin{array}{l}\text { Neem aktief deel aan } \\
\text { mekaarbediening }\end{array}$} \\
\cline { 2 - 5 } & $\begin{array}{l}\text { Gemeente- } \\
\text { lede moet } \\
\text { mekaar be- } \\
\text { dien }\end{array}$ & $\begin{array}{l}\text { Ek wil graag } \\
\text { mense bedien } \\
\text { in die gemeen- } \\
\text { te }\end{array}$ & $\begin{array}{l}\text { Gemeentelede } \\
\text { bedien mekaar } \\
\text { reeds genoeg- } \\
\text { saam }\end{array}$ & $\begin{array}{l}\text { Ek is } \\
\text { aktief by } \\
\text { n diens- } \\
\text { groep } \\
\text { betrokke }\end{array}$ \\
\hline $\begin{array}{l}\text { Baie betrokke } \\
\text { lidmate }\end{array}$ & 9,5 & 8,9 & 4,0 & 8,6 \\
\hline $\begin{array}{l}\text { Matig } \\
\text { betrokke } \\
\text { lidmate }\end{array}$ & 8,4 & 7,5 & 4,5 & 5,8 \\
\hline $\begin{array}{l}\text { Onbetrokke } \\
\text { lidmate }\end{array}$ & 8,3 & 6,9 & 5,1 & 2,6 \\
\hline Alle lidmate & 8,5 & 7,4 & 4,8 & 4,6 \\
\hline
\end{tabular}

Die gemeente stem bogemiddeld saam dat mekaarbediening noodsaaklik is (gemiddeld 8,46 op 'n 10-puntskaal) en wil ook graag self betrokke wees (gemiddeld 7,38). Lidmate glo egter self dat mekaarbediening nog nie ' $n$ werklikheid in die gemeente is nie. Daar was nie ' $n$ beduidende verskil tussen lidmate in verskillende lewensfases nie, maar daar was wel 'n verskil tussen betrokke en onbetrokke 
lidmate. 'n Mekaarbedieningsgesindheid hou regstreeks verband met die mate waartoe 'n lidmaat in die gemeente betrokke is. Vergelyk die oortuiging oor die belangrikheid van mekaarbediening van betrokke $(9,46)$ en onbetrokke $(8,33)$ lidmate. Let ook op hoe betrokke lidmate 'n meer realistiese oortuiging van die huidige sukses van mekaarbediening het $(4,03)$ teenoor onbetrokke lidmate $(5,14)$.

H2: Dit is moontlik om die bedieningskultuur van die gemeente so te verander dat gemeentelede aktief betrokke raak by 'n mekaarbediening. Dit is nie bevestig nie.

Die resultate van die empiriese ondersoek is aan die kerkleierskap gekommunikeer, maar die impak daarvan sal eers met verloop van tyd gesien kan word. ' $n$ Voorstel vir verdere navorsing is daarom om die navorsing in dieselfde gemeente te herhaal na vyf jaar om te toets of mekaarbediening 'n werklikheid geword het.

\section{- Struikelblokke wat betrokkenheid verhinder}

Tabel 7 is 'n opsomming van die kwantitatiewe data beskikbaar oor struikelblokke wat betrokkenheid verhinder. Hipoteses 3, 5, 8 en 9 kan aan die hand hiervan hersien word.

Tabel 7: Faktore wat betrokkenheid verhinder

\begin{tabular}{|l|c|}
\hline \multicolumn{1}{|c|}{ Struikelblok } & $\begin{array}{c}\text { Gemiddeld op 'n } \\
\text { 10-puntskaal }\end{array}$ \\
\hline Meer inligting nodig & 6,1 \\
\hline Vrye tyd & 5,8 \\
\hline Woon uitsluitlik aksies by wat deur ander gereël word & 5,6 \\
\hline lemand anders sal dit beter kan doen as ek & 5,5 \\
\hline lemand anders sal dit doen, ek hoef nie & 5,1 \\
\hline Voel nie welkom/vrymoedig nie & 4,5 \\
\hline Nie die regte opleiding/toerusting nie & 3,3 \\
\hline Daar val altyd iets voor & 2,7 \\
\hline Bang hulle verwerp my aanbod & 2,7 \\
\hline Woon net kerkdinge by as ek regtig nie anders kan nie & 2,7 \\
\hline
\end{tabular}

H3: Individuele betrokkenheid word verhinder deur 'n persoonlike gevoel van onbekwaamheid en 'n gebrek aan kennis. Dit is gedeeltelik bevestig. 
Die eerste geïdentifiseerde struikelblok wat moontlik betrokkenheid by bediening verhinder, is 'n gebrek aan bekwaamheid en toerusting. Verskeie struikelblokke uit Tabel 7 sluit by 'n gevoel van onbekwaamheid aan: Meer inligting nodig (gemiddeld van 6,13 op die 10-puntskaal), iemand anders sal dit beter kan doen, ek hoef nie $(5,45)$ en nie die regte opleiding/toerusting $(3,31)$. Ten spyte van verskeie toerustingsgeleenthede by die kerk was sommige gemeentelede huiwerig om betrokke te raak by die bediening. ' $n$ Minderheid lidmate het egter te kenne gegee dat hulle definitief nie vrymoedigheid het of welkom voel om hulle gawes in die gemeente te gebruik nie. Onsekerheid of hulle wel in staat is om bepaalde take te verrig, speel dus 'n belangrike rol in die onaktiwiteit (onbetrokkenheid) van lidmate. Toerustingsgeleenthede het dus nie hierdie onsekerheid weggeneem en lidmate bemagtig om bepaalde take met vertroue te kan aanpak nie. Toerusting moet sodanig geskied dat lidmate seker is dat hulle in staat is om ' $n$ bepaalde taak te verrig.

H4: Betrokkenheid word verhinder deur 'n gebrek aan persoonlike verantwoordelikheidsbesef. Dit is bevestig.

In 'n groter gemeente soos die Gereformeerde Kerk Randburg is dit maklik vir individue om in die groot groep "weg te raak". 'n Belangrike struikelblok wat na vore kom, is daarom die foutiewe aanname dat daar wel iemand anders in die gemeente is wat 'n betrokke taak sal afhandel. Die relatiewe prominensie van die struikelblokke lemand anders sal dit beter kan doen as ek (gemiddeld van 5,45 op die 10-puntskaal), en lemand ander sal dit doen, ek hoef nie $(5,10)$, wys daarop dat 'n beduidende deel van die gemeentelede nie seker is of hulle werklik in die bediening nodig is nie. 'n Algemene oproep tot betrokkenheid by 'n sekere taak, byvoorbeeld deur afkondigings of ander algemene kommunikasie sal daarom nie lei tot 'n persoonlike verantwoordelikheidsbesef en betrokkenheid nie. Lidmate moet persoonlik genader word om 'n besondere taak te verrig.

H5: Betrokkenheid word benadeel deur 'n algemene tekort aan vrye tyd in gemeentelede se persoonlike skedules. Dit is bevestig.

Vrye tyd is naas 'n gebrek aan inligting die grootste struikelblok. Die meeste lidmate het beperkte tyd beskikbaar om by die gemeente betrokke te wees. Indien die aktiwiteite waarby hulle betrokke kan raak meer tyd van hulle vra as wat hulle beskikbaar het, sal hulle liewer glad nie betrokke raak nie. Lidmate moet ook betrokke kan raak op 'n grondslag wat nie so baie tyd van hulle verg nie. Lidmate wat gewillig is om betrokke te raak, maar min tyd het, moet in ag 
geneem kan word. Omdat die vrye tyd van lidmate in verskillende lewensfases grotendeels verskil, is dit teoreties moontlik om tye waarin betrokkenheid nodig is, aan te pas volgens die beskikbaarheid van lidmate (bv. ouer mense en volwassenes met gesinne is nie later in die aande beskikbaar nie, terwyl jongmense juis laat in die aand beskikbaar is).

H6: Die verskille in die lewensomstandighede, prioriteite en behoeftes van gemeentelede in verskillende lewensfases het ' $n$ beduidende invloed op hulle betrokkenheid in die gemeente. Dit is bevestig.

Uit die ondersoek (vgl. Tabel 5) is dit duidelik dat verskillende lewensfases verskillende eise aan lidmate stel en ook verskillende prioriteite en behoeftes meebring. 'n Bedieningsmodel vir die gemeente sal aanpasbaar moet wees om hierdie verskille in ag te neem.

H7: Gemeentelede is oorafhanklik van die kerkleiers (ampte). Dit is bevestig.

In gesprek met gemeentelede oor die hantering van persoonlike probleme, het dit duidelik geword dat die meeste gemeentelede oorafhanklik van die leraars (predikante) is ten opsigte van die hantering van persoonlike probleme. Ten spyte van verskeie ander diensgroepe en persone wat hulp kan verleen, verkies die meeste om eerste die leraar met 'n probleem te kontak. Diensgroepe en die uitgebreide kerkraad word nie optimaal benut nie en dit plaas bykomende druk op die predikant. Hierdie hipotese is sterk in die kwantitatiewe data bevestig. Tabel 8 is 'n opsomming van die kontakpunte wat lidmate se eerste voorkeur is met 'n persoonlike probleem. Die data verwys na die persentasie lidmate wat die betrokke kontakpunt eerste met 'n probleem sal kontak. Die predikant word eerste deur $41 \%$ van die lidmate gekontak, terwyl slegs $2 \%$ die omgeebediening eerste sal kontak. 


\section{Tabel 8: Lidmate se eerste kontakpunt met 'n problem}

\begin{tabular}{|c|c|c|c|c|c|c|c|c|c|}
\hline \multicolumn{10}{|c|}{ Eerste kontakpunt met 'n probleem } \\
\hline & 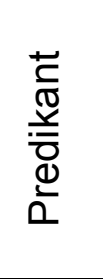 & 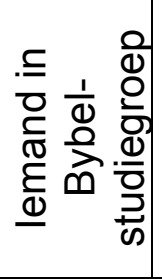 & $\begin{array}{l}\text { O) } \\
\frac{.}{\bar{D}} \\
\frac{0}{0} \\
\frac{0}{2} \\
0\end{array}$ & 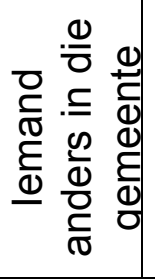 & 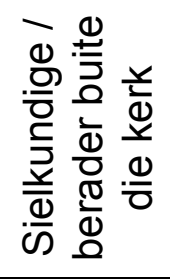 & 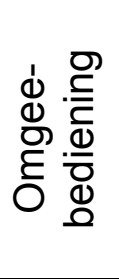 & $\begin{array}{l}\frac{c}{d} \\
\frac{\sqrt{0}}{0} \\
\frac{0}{0}\end{array}$ & 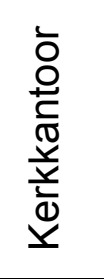 & $\begin{array}{l}\frac{1}{0} \\
\frac{0}{0} \\
\frac{c}{\alpha}\end{array}$ \\
\hline $\begin{array}{l}1 \mathrm{e} \\
\text { kontak }\end{array}$ & $41 \%$ & $19 \%$ & $10 \%$ & $10 \%$ & $10 \%$ & $2 \%$ & $1 \%$ & $1 \%$ & $6 \%$ \\
\hline $\begin{array}{l}2 \mathrm{e} \\
\text { kontak }\end{array}$ & $27 \%$ & $15 \%$ & $21 \%$ & $13 \%$ & $15 \%$ & $2 \%$ & $2 \%$ & $2 \%$ & $3 \%$ \\
\hline $\begin{array}{l}3 e \\
\text { kontak }\end{array}$ & $16 \%$ & $14 \%$ & $19 \%$ & $14 \%$ & $17 \%$ & $3 \%$ & $4 \%$ & $10 \%$ & $3 \%$ \\
\hline
\end{tabular}

Die meeste lidmate (68\%) sien steeds die predikant as eerste of tweede kontakpunt in die hantering van persoonlike probleme. Naas die leraar blyk Bybelstudiegroepe die sterkste alternatief te wees. Die ouderling is 'n populêre tweede of derde kontakpunt met 'n persoonlike probleem, in kontras met die diaken wat swakker presteer. Die rol van die omgeebediening was ten tye van die navorsing nog nie in die gemeente gevestig nie en lidmate verkies om deur 'n bekende gehelp te word. Oor die algemeen speel persoonlike verhoudings ' $n$ belangrike rol in die keuse van kontakpunt tydens 'n persoonlike probleem.

Lidmate is gevra om vir elke bedieningstaak aan te dui of dit slegs die lidmate, of sowel die lidmate as die kerkleiers (ampte), of slegs die kerkleiers (ampte) se verantwoordelikheid is. Van die bedieningstake wat getoets is, het lidmate die meeste as 'n gedeelde verantwoordelikheid tussen lidmate en die kerkleiers (ampte) beskou. Die werklikheid in die aktiwiteite van die gemeente word nie in hierdie data weerspieël nie. Die antwoorde gee dus 'n aanduiding van gesindheid en oortuiging eerder as werklike betrokkenheid by die bedieningstake. Die gesindheid moet ook in die werklike uitvoering van die take gestalte vind. Insig en gesindheid is iets wat deur die regte begeleiding benut kan word om groter betrokkenheid te verkry. 
Tabel 9: Persepsies van werksverdeling in die gemeente

\begin{tabular}{|l|c|c|c|}
\hline & $\begin{array}{c}\text { Slegs } \\
\text { lidmate }\end{array}$ & $\begin{array}{c}\text { Leiers } \\
\text { en } \\
\text { lidmate }\end{array}$ & $\begin{array}{c}\text { Slegs } \\
\text { leiers }\end{array}$ \\
\hline Meelewing, bv. ondersteun in nood & $5 \%$ & $93 \%$ & $2 \%$ \\
\hline Vir mense in die gemeente bid & $9 \%$ & $90 \%$ & $1 \%$ \\
\hline Help om geestelik te groei & $4 \%$ & $89 \%$ & $7 \%$ \\
\hline Gevoel van gemeenskap (koinonia) bevorder & $9 \%$ & $85 \%$ & $6 \%$ \\
\hline Ander lidmate tuis te laat voel & $14 \%$ & $84 \%$ & $2 \%$ \\
\hline Nuwe intrekkers besoek of uitnooi & $9 \%$ & $82 \%$ & $9 \%$ \\
\hline Lofprysing reël & $7 \%$ & $80 \%$ & $13 \%$ \\
\hline Geldinsameling vir mense in nood & $13 \%$ & $77 \%$ & $10 \%$ \\
\hline Nuwe diensgroep begin & $12 \%$ & $75 \%$ & $13 \%$ \\
\hline Help om Woord te verstaan & $4 \%$ & $67 \%$ & $29 \%$ \\
\hline
\end{tabular}

- Die bevordering van betrokkenheid wat tot volwassenheid lei

Tabel 10 en 11 is opsommings van die faktore wat betrokkenheid in die gemeente kan bevorder. Aangesien die faktore wat betrokkenheid kan bevorder ook (soos die struikelblokke) as stellings aangebied is en lidmate dan moes aandui of hulle saamstem of nie, word die data in Tabel 10 en 11 weer as 'n gemiddelde op 'n 10-puntskaal aangedui (waar hoër waardes aandui dat die lidmate saamstem met die stelling). Soos reeds bespreek, is die steekproef in drie groepe verdeel ten opsigte van betrokkenheid. Beduidende verskille is waargeneem tussen die antwoorde van betrokke en onbetrokke lidmate. Die verskil word daarom ook tussen hierdie groepe aangedui. 


\section{Tabel 10: Faktore wat betrokkenheid kan bevorder}

Faktore wat betrokkenheid kan bevorder (Gemiddeld op 'n 10-puntskaal)

\begin{tabular}{|l|c|c|c|c|}
\hline & $\begin{array}{l}\text { Verskil kan } \\
\text { maak met my } \\
\text { unieke } \\
\text { talente }\end{array}$ & $\begin{array}{l}\text { Persoonlik } \\
\text { nader en vra } \\
\text { om deel te } \\
\text { neem }\end{array}$ & $\begin{array}{l}\text { Geroepe } \\
\text { te voel }\end{array}$ & $\begin{array}{l}\text { Stel ander } \\
\text { funksies af } \\
\text { vir kerk- } \\
\text { dinge }\end{array}$ \\
\hline Baie betrokke lidmate & 9,1 & 7,1 & 7,2 & 7,9 \\
\hline Matig betrokke lidmate & 7,5 & 6,6 & 6,4 & 5,8 \\
\hline Onbetrokke lidmate & 7,3 & 7,1 & 6,7 & 4,9 \\
\hline Alle lidmate & 7,6 & 6,9 & 6,6 & 5,6 \\
\hline
\end{tabular}

H8: Betrokkenheid sal bevorder word deur toerusting en deur take so spesifiek moontlik vir die individu te maak. Dit is bevestig.

Hierdie hipotese is sterk in die empiriese ondersoek bevestig. Die faktore (wat in die kwalitatiewe fase geïdentifiseer is) wat moontlik betrokkenheid kan bevorder (en as hipoteses in die kwantitatiewe fase bevestig is), beklemtoon almal die tema van individuele betekenis in betrokkenheid. Om 'n verskil te maak met my eie talente en om geroepe te voel (albei met bogemiddelde waardes op die 10puntskaal), is vir die meeste belangrik. Veral lidmate wat reeds aan die werk is (baie betrokke), het besonder sterk aangedui $(9,1)$ dat hulle graag op 'n terrein wil werk waar hulle unieke gawes het. Hierby sluit die oortuiging aan - wat sterk by alle lidmate leef - dat hulle besig wil wees met iets waarvoor hulle deur die Here geroepe voel, en dat hulle persoonlik genader wil word om daarby betrokke te raak. Wanneer lidmate begelei word om hulle gawes te ontdek, asook die plek waar hulle dit kan aanwend en hulle word prakties toegerus daarvoor, kan dit betrokkenheid verhoog.

'n Vergelyking tussen betrokke en onbetrokke lidmate bevestig dat die lewering van 'n unieke bydrae die belangrikste motivering vir betrokke lidmate is. Vir hierdie groep lidmate het hulle betrokkenheid al na lojaliteit en prioritisering oorgeskakel.

H9: Betrokkenheid sal bevorder word deur 'n gesindheidsverandering by gemeentelede oor die mekaarbediening. Dit is nie bevestig nie. 
Die gemeente is tot 'n groot mate oortuig dat die Here vra dat ons mekaar moet bedien. Baie lidmate is ook gewillig om dit te doen. Die oortuiging en gewilligheid lei egter by baie nie noodwendig tot aksie nie. 'n Gesindheidsverandering moet dus ook gepaard gaan met strukturele aanpassings om die oortuiging en gewilligheid tot aksie aan te spoor.

H10: Gemeentelede is nie sosiaal met mekaar bekend nie en betrokkenheid sal bevorder word indien gemeentelede mekaar leer ken. Dit is bevestig.

Die ondersoek toon 'n regstreekse korrelasie aan tussen lidmate se betrokkenheid en sosiale vriendskappe binne die gemeente. Lidmate wat baie betrokke is, het ook meestal baie sosiale vriende binne die gemeente en niemand wat baie betrokke is, het aangedui dat hy/sy geen kerkvriende het nie. Soos die betrokkenheid afneem, neem die aantal vriende in die kerk ook af.

\section{Tabel 11: Die invloed van vriendskappe op betrokkenheid}

\begin{tabular}{|c|c|c|c|c|c|c|}
\hline & 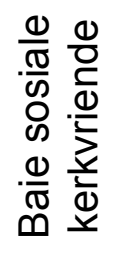 & 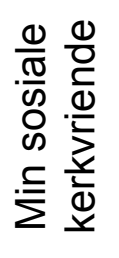 & 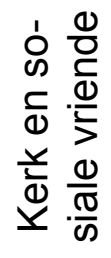 & 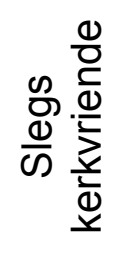 & 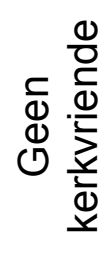 & 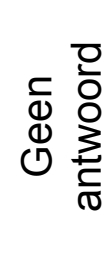 \\
\hline Baie betrokke lidmate & $49 \%$ & $16 \%$ & $19 \%$ & $11 \%$ & $0 \%$ & $5 \%$ \\
\hline Matig betrokke lidmate & $29 \%$ & $26 \%$ & $15 \%$ & $16 \%$ & $8 \%$ & $6 \%$ \\
\hline Onbetrokke lidmate & $13 \%$ & $26 \%$ & $10 \%$ & $12 \%$ & $20 \%$ & $19 \%$ \\
\hline
\end{tabular}

Dit is moeilik bepaalbaar wat eerste is, betrokkenheid of vriendskap. Die werkbare aanname sou wees dat dit in albei rigtings werk. Lidmate wat vriende in die gemeente het, sal makliker saam met die vriende kan betrokke raak, en lidmate wat uit hulle eie betrokke raak, sal waarskynlik binne die gemeente vriende maak. Sosiale betrokkenheid by mekaar is egter duidelik uitgewys as 'n faktor in betrokkenheid by die gemeente. Een manier om sosiale betrokkenheid te bevorder, is die instelling van Bybelstudiegroepe. Tabel 12 vergelyk die betrokkenheid van lidmate wat deel is van 'n Bybelstudiegroep en lidmate wat nie deel is van so 'n groep nie. Let op dat $62 \%$ van lidmate wat nie by 'n Bybelstudiegroep inskakel nie, as onbetrokke lidmate geklassifiseer is. Slegs $4,9 \%$ van lidmate wat nie deel is van 'n Bybelstudiegroep nie, skakel genoegsaam by ander aktiwiteite in om as betrokke lidmate geklassifiseer te word. 
Tabel 12: Die invloed van Bybelstudiegroepe op betrokkenheid

\begin{tabular}{|l|c|c|c|}
\hline & $\begin{array}{c}\text { Baie betrokke } \\
\text { lidmate }\end{array}$ & $\begin{array}{c}\text { Matig betrokke } \\
\text { lidmate }\end{array}$ & $\begin{array}{c}\text { Onbetrokke } \\
\text { lidmate }\end{array}$ \\
\hline Deel van 'n Bybelstudiegroep & $22,4 \%$ & $51,4 \%$ & $26,2 \%$ \\
\hline $\begin{array}{l}\text { Nie deel van 'n Bybelstudie- } \\
\text { groep nie }\end{array}$ & $4,9 \%$ & $32,6 \%$ & $62,5 \%$ \\
\hline
\end{tabular}

\section{Riglyne vir die ontwikkeling van 'n bedieningsplan}

\subsection{Toerusting wat lidmate vir 'n bepaalde taak bekwaam}

Lidmate het aangedui dat hulle bereid is om dienswerk te verrig, maar dat hulle onseker is of hulle dit kan doen, en of daar nie miskien iemand is wat meer geskik vir die werk is nie. Kursusse wat by die oordra van die teorie ophou, het nie vrymoedigheid bewerk nie (vgl. H1, H3, H9).

Prediking en kursusse wat die bybelse beginsels onderrig, kan kennis oordra en gesindheid verander, maar sal nie noodwendig die lidmaat die vrymoedigheid gee om sy/haar gawes in die gemeente aan te wend nie. Toerusting moet op 'n bepaalde taak gerig wees (taakspesifiek). Wanneer 'n behoefte in die gemeente bestaan of ' $n$ diensgroep met 'n bepaalde taak besig is, moet 'n kursus wat spesifiek op toerusting hiervoor gerig is, saamgestel word. Kursusse moet ook so ver moontlik praktiese inoefening insluit. Die resep van "vertel iemand waarom en hoe dit gedoen moet word, wys hom hoe dit gedoen word, begelei hom om dit self te doen en laat hom dit self doen", moet gevolg word. Die strukture van die gemeente moet ook toegang tot dienswerk fasiliteer. Opvolging by lidmate wat kursusse deurloop het, is belangrik, sodat hulle aktief begelei word om vertroue op te bou daarin dat hulle nodig is in die bediening en 'n bydrae daartoe kan lewer.

\subsection{Individuele werwing van lidmate vir besondere take}

Lidmate het aangedui dat hulle nie seker is of hulle werklik in die bediening van die gemeente nodig is nie (vgl. H4 \& H8). Individuele werwing van lidmate vir 'n bepaalde taak in die gemeente kan 'n belangrike rol speel om lidmate betrokke te kry. Hierin kan kursusse waarin lidmate hulle gawes kan ontdek 'n belangrike rol speel. Vanuit die resultate van hierdie kursusse kan lidmate betrokke raak by dienswerk waar hulle gawes van nut kan wees. Wyksbediening moet ook sodanig gestruktureer word dat wykslede spesifieke verantwoordelikheid ontvang. Lidmate moet sover moontlik by 'n klein- 
groep (wyk of diensgroep) ingeskakel word en daar 'n spesifieke verantwoordelikheid ontvang.

\subsection{Aanpasbaarheid van 'n bedieningsplan}

Dit is onmoontlik om die sukses van 'n bedieningsplan te bepaal voordat dit nie vir 'n tyd lank toegepas is nie (vgl. H2). Voortdurende en geskeduleerde evaluering van 'n bedieningsplan is noodsaaklik om die mate van sukses daarvan te bepaal, swak punte te identifiseer en nuwe insigte te bewerkstellig. Die veranderende situasie binne 'n gemeente kan sodoende telkens verwerk word en neerslag vind in veranderings aan die bedieningsplan.

\subsection{Betrokkenheid volgens beskikbare tyd}

Lidmate het aangedui dat vrye tyd 'n baie skaars kommoditeit is en dat hulle daarom nie betrokke raak in die gemeente nie (H5).

Indien betrokkenheid by die bediening beteken dat lidmate meer tyd daaraan sal moet bestee as wat hulle dink hulle beskikbaar het, gaan hulle nie aan hierdie aktiwiteit deelneem nie. Dit kan dus beteken dat die lidmaat niks doen nie. Dit gee daartoe aanleiding dat 'n kleiner groep alles moet doen terwyl ander niks doen nie. Die tendens is dat wanneer iemand betrokke raak, hy/sy net al hoe meer take opgelê word, en dan op 'n stadium net nie meer kans sien vir alles nie en terugtrek. Dit kan veroorsaak dat so 'n lidmaat in die toekoms glad nie betrokke sal wil raak nie, omdat hy/sy bang is om weer oorlaai te word. Die bedieningstruktuur moet dit moontlik maak dat elke lidmaat betrokke kan raak in sover sy beskikbare tyd hom/haar toelaat. In plaas daarvan dat hy/sy byvoorbeeld diaken word van 'n hele wyk, kan net een lidmaat of gesin se versorging aan hom/haar opgedra word.

\subsection{Sosiale betrokkenheid}

Sosiale betrokkenheid en betrokkenheid by die bediening is baie nou aan mekaar gekoppel (vgl. H10). 'n Bedieningsplan moet doelbewus die geleentheid skep dat meer en meer lidmate mekaar goed kan leer ken en die moontlikheid om vriendskappe te sluit, vergroot. Kleingroepe wat gereeld bymekaarkom of gereeld saamwerk, kan hierin diensbaar wees. Kleingroepe moet daarop ingestel wees om sosiale interaksie te bevorder. 


\section{Voorstelle vir verdere navorsing}

'n Poging is aangewend om minder aktiewe lede van die gemeente in te sluit, maar as gevolg van ' $n$ inherente leemte in die data-insamelingsmetodes wat gebruik is, is hierdie groep minder verteenwoordig in die kwalitatiewe en kwantitatiewe steekproewe. Dit is moontlik dat gemeentelede wat aan die navorsing deelgeneem het (wat bereid was om fokusgroepe by te woon, wat die elektroniese vraelys ingevul het, of meer waarskynlik wat die eredienste bygewoon het), reeds meer geneig was om aan aktiwiteite deel te neem of reeds daarvoor oop was. Verdere navorsing moet die toepaslikheid van die bevindings toets vir gemeentelede wat nie aktief by die kerk betrokke is nie en waarskynlik nie eredienste bywoon nie.

Die Gereformeerde Kerk Randburg is 'n groot stadsgemeente. 'n Voorstel vir verdere navorsing is dat soortgelyke studies in plattelandse gemeentes en kleiner stadsgemeentes gedoen word om vas te stel of die bevindings van hierdie studie uniek is aan die spesifieke konteks van die gemeente.

'n Verdere voorstel vir navorsing is om vas te stel of die wyksverdeling van die Gereformeerde Kerk Randburg 'n invloed op betrokkenheid in die gemeente het. Gemeente-aktiwiteite word dikwels binne wyksverband aangebied en dit is moontlik dat hierdie feit sosiale vriendskappe bevorder, omdat gemeentelede met mense binne hulle eie lewensfase sosialiseer.

Die kwalitatiewe bevindings dat prioriteite en vryetydsbesteding in unieke lewensfases verskil, kan moontlik aandui dat dit makliker en meer aangenaam vir gemeentelede is om aan aktiwiteite deel te neem binne hierdie wyksverband. Dit is 'n veranderlike wat nie in die huidige studie empiries getoets kon word nie, omdat die hele studie binne die betrokke gemeente uitgevoer is. Navorsing is daarom nodig om betrokkenheid in 'n gemeente met 'n wyksverdeling volgens lewensfases te vergelyk met betrokkenheid in 'n gemeente waar wyke geografies verdeel is.

'n Bedieningsmodel wat gebruikmaak van die data wat deur hierdie studie verkry is, kan ontwikkel word.

\section{Geraadpleegde bronne}

BREED, G. \& BREED, D.G. 2010. Besinning oor die diakonale dienswerk na aanleiding van Handelinge 6:1-7. In die Skriflig, 44(3 \& 4):627-653. 
HEIMBROCK, H. 2005. From data to theory: elements of methodology in empirical phenomenological research in practical theology. International journal of practical theology, 9(2):273-299.

KRUGER, S.F. 2005. Toerusting as wordingsproses: perspektiewe uit die Efesiërbrief. In die Skriflig, 39(3):527-553.

MARIAMPOLSKI, H. 2001. Qualitative research: a comprehensive guide. Thousand Oaks: Sage.

NEL, M. 2009. Congregational analysis: a theological and ministerial approach. HTS teologiese studies/theological studies, 65(1):1-17. (http://www.hts. org.za)

RATNER, C. 2001. Analyzing cultural-psychological themes in narrative statements. Forum: qualitative social research, 2(3):1-8.

RYAN, G.W. \& BERNARD, H.R. 2003. Techniques to identify themes. Field methods, 15(1):85-109.

SCHWARZ, C.A. 1996, Natural church development: a guide to eight essential qualities of healthy churches. Carol Stream: ChurchSmart Resources.

STRUWIG, O.J. 2004. Die verhouding gemeenskap van die gelowiges en die dienswerk van die diakens: 'n prakties-teologiese studie, met spesifieke verwysing na die "sewe" (Handelinge 6). Potchefstroom, NWU. (M.Th.skripsie.)

VAN DER VEN, J.A. 2002. An empirical or a normative approach to practical theological research? Journal of empirical theology, 15(2):5-33.

VERSTEEG, J.P. 1980. Oog voor elkaar: het gebruik van het woord "elkaar" in het Nieuwe Testament met betrekking tot de onderlinge verhoudingen binnen de gemeente. Kampen: Kok.

WOOLEVER, C. \& BRUCE, D. 2004. Beyond the ordinary: 10 strengths of US congregations. Louisville: Westminster John Knox Press.

\section{Kernbegrippe:}

bedieningsmodel

empiriese ondersoek

volwasse gemeente

\section{Key concepts:}

ministry model

empirical study

mature congregation 
Op pad na 'n volwasse gemeente - 'n empiriese ondersoek ... bedieningsmodel 